\title{
Effects of deoxynivalenol (DON) and its microbial biotransformation product deepoxy-deoxynivalenol (DOM-1) on a trout, pig, mouse, and human cell line
}

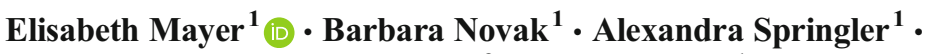 \\ Heidi E. Schwartz-Zimmermann ${ }^{2}$ - Veronika Nagl ${ }^{1}$. Nicole Reisinger ${ }^{1}$ • \\ Sabine Hessenberger ${ }^{1} \cdot$ Gerd Schatzmayr $^{1}$
}

Received: 6 March 2017 /Revised: 13 July 2017 / Accepted: 14 July 2017 /Published online: 24 July 2017

(C) The Author(s) 2017. This article is an open access publication

\begin{abstract}
Deoxynivalenol (DON), a trichothecene produced by various Fusarium species, is one of the most prevalent food- and feed-associated mycotoxins. The effects of DON and deepoxy-deoxynivalenol (DOM-1) were assessed in five different cell lines from different tissues and species starting from the first line of defense, the trout gill (RTgill-W1) and pig intestinal cells (IPEC-1 and IPEC-J2) over immune cells, as second line of defense (mouse macrophages RAW 264.7) to human liver cells (HepG2). Viability was assessed with a WST-1 assay, except for RTgill-W1, where a neutral red (NR) and sulforhodamine B (SRB) assay was performed. Additionally, more sensitive parameters, such as interleukin-, nitric oxide (NO)-, and albumin-release were determined. Viability was affected by DON at concentrations starting at $10 \mu \mathrm{mol} / \mathrm{L}$ (RTgill-W1), $0.9 \mu \mathrm{mol} / \mathrm{L}$ (IPEC-1), $3.5 \mu \mathrm{mol} / \mathrm{L}$ (IPEC-J2), and $0.9 \mu \mathrm{mol} / \mathrm{L}(\mathrm{HepG} 2)$, whereas DOM-1 did not have such an effect. Additionally, NO was decreased $(0.84 \mu \mathrm{mol} / \mathrm{L}$ DON), whereas interleukin (IL)-6 was increased $(0.42 \mu \mathrm{mol} / \mathrm{L}$ DON) in lipopolysaccharide (LPS)-stimulated DON-, but not DOM-1-treated RAW cells. Tumor necrosis factor (TNF)- $\alpha$ release, however, was not affected. Interestingly, albumin secretion of HepG2 cells was decreased by both DON and DOM-1 but at a much higher concentration for DOM-1 (228 versus $0.9 \mu \mathrm{mol} / \mathrm{L}$ for DON). $98.9 \%$ of
\end{abstract}

Elisabeth Mayer

e.mayer@biomin.net

BIOMIN Research Center, Technopark 1, 3430 Tulln an der Donau, Austria

2 Christian Doppler Laboratory for Mycotoxin Metabolism, Center for Analytical Chemistry, Department of Agrobiotechnology (IFA-Tulln), University of Natural Resources and Life Sciences, Vienna, 3430 Tulln an der Donau, Austria
DOM-1 was retrieved by liquid chromatography tandem mass spectrometry at the end of the experiment, proving its stability. In this study, IL-6 was the most sensitive parameter, followed by $\mathrm{NO}$ and albumin release and viability for HepG2 and IPEC-1.

Keywords Cell culture - Cytotoxicity · Contamination . Feedstuff $\cdot$ Metabolite $\cdot$ Transformation $\cdot$ Toxicity $\cdot$ Cell lines . Fish $\cdot$ In vitro

$\begin{array}{ll}\text { Abbreviations } \\ \text { DOM-1 } & \text { deepoxy-deoxynivalenol } \\ \text { DON } & \text { deoxynivalenol } \\ \text { IPEC } & \text { intestinal porcine epithelial cells } \\ \text { LC-MS/ } & \text { liquid chromatography tandem mass } \\ \text { MS } & \text { spectrometry } \\ \text { LPS } & \text { lipopolysaccharide } \\ \text { NO } & \text { nitric oxide } \\ \text { NR } & \text { neutral red } \\ \text { SRB } & \text { sulforhodamine B } \\ \text { TNF } & \text { tumor necrosis factor } \\ \text { WST-1 } & \text { water-soluble tetrazolium salt-1 }\end{array}$

\section{Introduction}

Mycotoxins, toxic secondary metabolites of fungi, are a severe problem in agriculture and animal husbandry. Worldwide surveys revealed their widespread prevalence, with up to $72 \%$ of agricultural commodities being contaminated (Schatzmayr and Streit 2013). Deoxynivalenol (DON), a type B trichothecene produced by various Fusarium spp., is less toxic than some of its related trichothecenes (e.g., nivalenol, T-2 toxin), 
but still the most prevalent and economically most important mycotoxin in cereal production. Maximum levels and/or guidance values regulating its concentrations in food and feed have therefore been established (European Commission 2006).

DON can be biotransformed by different anaerobic ruminal or intestinal microbes (McCormick 2013). One example for a microbial biotransformation product is deepoxy-deoxynivalenol (DOM-1), which was first described in rats and mice by Yoshizawa et al. (1983) and is formed through cleavage of the 12,13-epoxy ring by bovine rumen microorganisms, such as Genus novus (formerly Eubacterium) species novus BBSH 797 of the Coriobacteriaceae family (Fuchs et al. 2002). BBSH 797 is the first-ever microorganism to be cultured, produced, and authorized for its use as a feed additive (European Commission 2013; EFSA 2013a). With the use of these feed additives, DOM1 gains importance and food safety has to be assured (European Commission 2013). Few studies on DOM-1 are available and regulatory limits for DON metabolites, such as DON glucuronides or DON sulfonates, have not yet been set due to lack in data for absorption and toxicity (EFSA 2013b). For the parent toxin DON, the situation is different, as it has been studied for decades. In general, DON leads to a decrease in feed intake, reduced weight gain, and higher susceptibility to bacterial infections in animals (CAST 2013). Its toxicity on terrestrial animals, especially poultry and pigs, is well documented (Broekaert et al. 2016; Schwartz-Zimmermann et al. 2015). Effects on aquatic animals are however poorly studied, focusing on in vivo studies, assessing only growth and weight (Anater et al. 2016). Due to expansion of the aquaculture industry and the rising costs of fish meal, the use of plant-derived proteins - such as soy bean and other grains as alternative protein sources - quickly increased their demand (Fry et al. 2016). Accordingly, the risk of introducing mycotoxins into animal feed has increased as well, resulting in elevated costs for fish production and decreased animal health. Most investigations have focused on aflatoxin B1 due to its particularly high toxicity (Dirican 2015). The potential effect of DON, despite its frequent occurrence in aquaculture feeds (Gonçalves et al. 2016), has gained increased interest in the last years (Tolosa et al. 2014, Greco et al. 2015, Pietsch et al. 2015, Pelyhe et al. 2016). The European Commission sets the maximum DON concentration at $5 \mathrm{mg} / \mathrm{kg}$ for fish feed, which is over 5.5 times greater than the maximum suggested concentration for pig feed $(0.9 \mathrm{mg} / \mathrm{kg}$ ) (European Commission 2006). High DON sensitivity has already been observed in rainbow trout, where DON significantly decreased weight gain, feed intake, and feed efficiency at concentrations above $0.5 \mathrm{mg} / \mathrm{kg}$ DON in feed (Hooft et al. 2011). Information about the in vitro effects of DON on fish cells is scarce (Hooft et al. 2011) and effects of DOM-1 have never been assessed in a fish cell line. As the actual concentrations encountered by fish stocks due to agricultural run-off in lakes and rivers are unknown (Hoerger et al. 2009) and watersoluble mycotoxins, like DON, can accumulate in aquaculture, additional research on the effects of DON and DOM-1 is required to facilitate good husbandry practice and to ensure animal welfare.

In contrast to fish, the effects of DON on swine- and pigderived cells have been studied extensively (Dänicke et al. 2010; Wan et al. 2013). DON compromises gut barrier function, reduces expression of tight junction proteins (Pinton et al. 2012; Springler et al. 2016b), and downregulates multiple transporter systems in enterocytes, impairing nutrient absorption (Ghareeb et al. 2015; Maresca 2013). It is quickly absorbed in the upper part of the porcine gastrointestinal tract (Dänicke et al. 2004b; Grenier and Applegate 2013) and is only moderately biotransformed to DOM-1 by intestinal microbiota in the hindgut (Nagl et al. 2014). Therefore, the effects of DON and DOM-1 were studied and compared in proliferating intestinal porcine epithelial cell lines, IPEC-1 and IPEC-J2.

Immune cells, such as macrophages, T cells, and B cells, present important targets for DON. On a cellular level, inhibition of protein synthesis is regarded as the main effect (Ehrlich and Daigle 1987). Quickly proliferating cells, such as immune cells, with a high protein turnover, are therefore especially sensitive to this mycotoxin. Depending on dose, exposure, frequency, and timing, DON can either stimulate or suppress immunological parameters, such as immunoglobulins and cytokines (Pestka et al. 2004). Macrophages play a major role in host defense against infections through production of mediators such NO, hydrogen peroxide, and cytokines (Lorsbach et al. 1993). Therefore, using murine macrophages, we assessed the effects of DON on viability and $\mathrm{NO}$ release and compared these to the release of the cytokines IL- 6 and TNF- $\alpha$.

Following intestinal absorption, DON reaches the liver via the portal vein. As both, intestine and liver with their quickly proliferating cells, have a high protein turnover rate (Savard et al. 2015), they are considered as DON-sensitive organs (Ueno 1984). Following oral consumption of DON, negative effects on liver and serum parameters were found (D'Mello et al. 1999). In the porcine liver, DON concentrations reached maximal values of $4.8 \mathrm{ng} / \mathrm{g}(\sim 0.1 \mu \mathrm{mol} / \mathrm{L})$, irrespective of the inclusion rate in the feed $(0.55-1.23 \mathrm{mg} / \mathrm{kg})$. DOM- 1 , however, was only detected in the liver $(0-2.4 \mathrm{ng} / \mathrm{g}$ $(\sim 0.0033 \mu \mathrm{mol} / \mathrm{L})$ (Döll et al. 2008). To assess the effect of DON on liver cells and due to a lack of a commercially available hepatocellular cell line for pigs, a human hepatocellular cell line (HepG2) was used to compare the effects of DON and DOM-1 on viability and albumin release. Albumin is synthesized in the liver and comprises about one-half of the blood serum protein.

The aim of the study was to assess the effects of DON and DOM-1 on five different cell lines of different animal origin, starting from the first line of defense, the gill and intestinal cells over immune cells, as second line of defense, to liver cells. Particularly, studies of DOM-1 cytotoxicity are scarce and its stability in a culture system as well as its effects on a 
fish cell line has never been assessed before. Viability was determined with a WST-1 (water-soluble tetrazolium) assay, except for RTgill-W1, where a NR and SRB assay had to be performed. Additionally, more sensitive parameters, such as interleukin- (IL-6 and TNF- $\alpha$ ), NO-, and albumin-release, were assessed.

\section{Materials and methods}

\section{Chemicals and reagents}

HyClone Leibovitz L-15 was purchased from GE Healthcare Life Sciences, Marlborough, MA, USA, DMEM/Ham's F12 and DMEM (4.5 g/L glucose) were purchased from Biochrom AG, Berlin, Germany, and RPMI, penicillin-streptomycin (P/S), and HEPES (4-(2-hydroxyethyl)-1-piperazineethanesulfonic acid) were purchased from Sigma-Aldrich, St. Louis, MO, USA. Lglutamine (L-glut), insulin-transferrin-selenium (ITS), epidermal growth factor (EGF), and fetal bovine serum (FBS) were purchased from Gibco ${ }^{\mathrm{TM}}$, Life Technologies, Carlsbad, CA, USA.

DON (Biopure, Romer Labs®, Tulln, Austria) was dissolved in distilled water $(6.75 \mathrm{mmol} / \mathrm{L})$ and further diluted with the respective media. DOM-1 (Biopure, Romer Labs ${ }^{\circledR}$, Tulln, Austria) was obtained in acetonitrile $(180.1 \mu \mathrm{mol} / \mathrm{L})$, evaporated with nitrogen, and further diluted with the respective media. Contaminations of $0.1-0.2 \%$ DON and $3 \%$ isoDOM-1 were detected via LC-MS/MS. The calculated solubility (Marvin Software Version 17.9.0, 2017, ChemAxon, (http://www.chemaxon.com)) in water at $\mathrm{pH} 7$ was 14 . $51 \mathrm{mg} / \mathrm{mL}(\sim 49 \mathrm{mmol} / \mathrm{L})$ for DON and $11.15 \mathrm{mg} / \mathrm{mL}$ ( $\sim 40 \mathrm{mmol} / \mathrm{L})$ for DOM-1, thus, used concentrations were far below the solubility threshold.

\section{Cell culture}

RAW 264.7 (ATCC® TIB71 ${ }^{\mathrm{TM}}$ ) and RTgill-W1 cells (ATCC® CRL. 2523 ${ }^{\mathrm{TM}}$ ) were obtained from ATCC (American Type Culture Collection, Manassas, VA, USA). IPEC-1 (ACC-705), IPEC-J2 (ACC-701), and HepG2 (ACC-180) were purchased from DSMZ (German Collection of Microorganisms and Cell Cultures, Braunschweig, Germany). The cells were cultured in respective cultivation media recommended by the supplier and maintained in monolayers in $75-\mathrm{cm}^{2}$ culture flasks (Starlab, Hamburg, Germany) in a humidified incubator at designated temperatures (Table 1). Viability was assessed in triplicates in 96-well plates (Eppendorf, Hamburg, Germany), if not stated otherwise. Mycoplasma tests were performed bimonthly to confirm that cells were free of mycoplasma contamination (Venor® GeM Mycoplasma Detection Kit; Minerva Biolabs, Berlin, Germany).

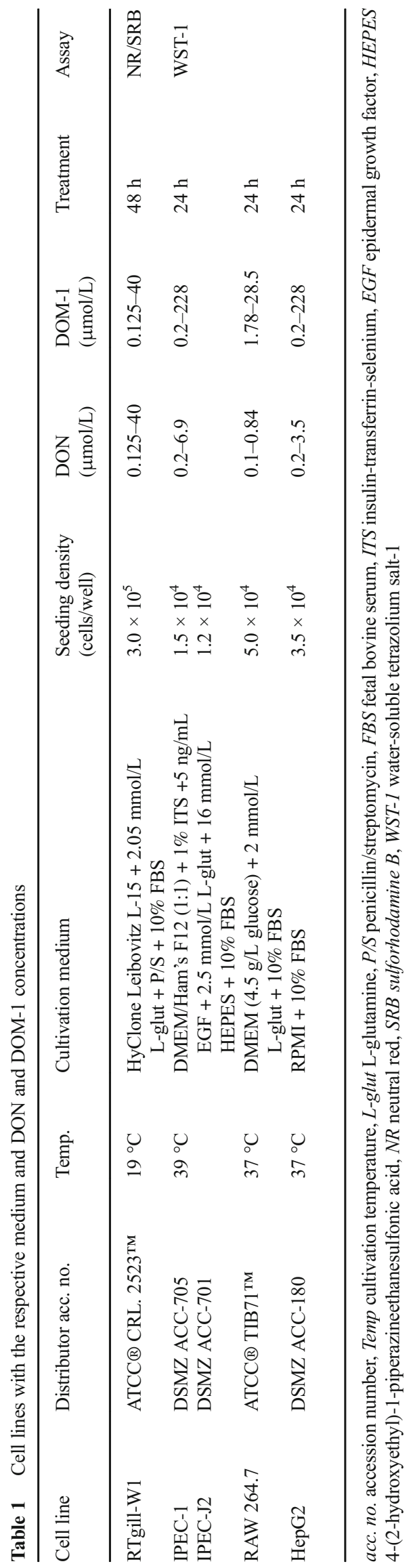


RTgill-W1

The rainbow trout (Oncorhynchus mykiss) epithelial gill cell line RTgill-W1 was cultured according to Table 1 in normal atmosphere (ambient gas composition $21 \% \mathrm{O}_{2}, 78 \% \mathrm{~N}_{2}$, and $0.04 \% \mathrm{CO}_{2}$ ) (Bols et al. 1994). The cells were seeded and cultured in 96-well flat-bottom plates for $72 \mathrm{~h}$ and subsequently treated with DON or DOM-1 for $48 \mathrm{~h}$. A NR and SRB assay (both Aniara, West Chester, OH, USA) were performed, as the WST-1 assay (which was applied for all other cell lines) as well as the 24-h incubation time did not fulfill the manufacturer's performance standards (OD of 1 for cell control was not reached). Experiments were performed in three (NR) and four (SRB) independent experiments.

\section{NR and SRB assay}

A dual-parameter assay, using a NR assay, targeting the lysosomal activity, followed by a SRB assay, targeting the total protein content (and not the de novo protein synthesis), was carried out to assess cell viability. Both assays were performed according to the manufacturer's instructions. Briefly, NR was added (1:100 in medium), incubated for $3 \mathrm{~h}$, fixed for $1 \mathrm{~min}$, and subsequently dissolved. Absorbance was measured at $540 \mathrm{~nm}$, with a reference filter of $690 \mathrm{~nm}$. Thereafter, a SRB assay was performed in the same well. In short, cells were washed, fixed and incubated with SRB for $15 \mathrm{~min}$, washed again, and dissolved, and absorbance was measured at $540 \mathrm{~nm}$, with a reference filter of $690 \mathrm{~nm}$.

\section{IPEC-1 and IPEC-J2}

To compare the spontaneously immortalized, non-transformed, intestinal porcine epithelial cells IPEC-1 and IPECJ2 (Gonzalez-Vallina et al. 1996; Schierack et al. 2006), they were cultured according to Table 1 and cultivated in vitro for a maximum of 15 passages. Cells were seeded in 96-well flatbottom plates, incubated for $48 \mathrm{~h}$, and then treated with DON or DOM-1 for $24 \mathrm{~h}$. Viability was assessed via the WST-1 assay and expressed as percent compared to a joint cellcontrol of three independent experiments, which was set to 100.

\section{WST-1 assay}

Cell proliferation reagent WST-1 (4-[3-(4-iodophenyl)-2-(4nitrophenyl)-2H-5-tetrazolio]-1,3-benzene disulfonate) assay (Roche, Switzerland) was performed according to the manufacturer's instructions. Briefly, the cells were incubated with a $5 \%$ WST-1 solution in medium for a maximum of $4 \mathrm{~h}$ at designated temperatures and quantified via spectrometry at $450 \mathrm{~nm}$. The development of formazan dye correlates to the number of metabolically active cells in the culture.

\section{$R A W 264.7$}

The cells were cultured according to Table 1. RAW 264.7 macrophages were seeded in 96-well flat-bottom plates, incubated for $24 \mathrm{~h}$, and subsequently stimulated with and without LPS from Escherichia coli O111:B4 (1 $\mu \mathrm{g} / \mathrm{mL})$ (SigmaAldrich, St. Louis, MO, USA) and DON or DOM-1 for a further $24 \mathrm{~h}$. Subsequently, the supernatant was collected for NO and cytokine determination. A WST-1 assay was performed thereafter, to assess viability. Experiments were performed in five independent experiments.

\section{NO measurement}

The amount of NO in supernatants of RAW 264.7 macrophages was determined via the Griess diazotization reaction (Roche, Basel, Switzerland). Fifty microliters of cell supernatant was used for NO determination. The remaining supernatant was stored at $-20{ }^{\circ} \mathrm{C}$ for cytokine determination. Experiments were performed in five independent experiments.

Absorbance was measured at $540 \mathrm{~nm}$ using a microplate reader. Relative NO release was calculated as follows:

$\mathrm{NO}$ release $(\%)=((\mathrm{NO}$ concentration of LPS-treated $-\mathrm{NO}$ concentration sample-treated $) / \mathrm{NO}$ concentration LPS-treated $) \times 100$

\section{Cytokine determination}

IL-6 and TNF- $\alpha$ were determined in RAW 264.7 cell supernatant in duplicates by a multiplex bead-based flow cytometric assay (Flow Cytomix ${ }^{\mathrm{TM}}$, eBioscience, Austria). Thawed supernatant was centrifuged and $25 \mu \mathrm{L}$ was treated according to the instructions of the manufacturer and thereafter measured by the flow cytometer Accuri C6 ${ }^{\mathrm{TM}}$ (BD, Heidelberg, Germany) using the BD Sampler Analysis Software. Standard curves were determined for each cytokine in a range of 27-20,000 pg/mL. Cytokine concentration was expressed as percent compared to a joint LPS-control of three independent experiments, which was set to 100 . 


\section{Hep $G 2$}

The human hepatocellular carcinoma cell line HepG2 was cultured according to Table 1. For viability assays, HepG2 cells were seeded, incubated for $48 \mathrm{~h}$, and then treated with varying concentrations of DON $(0.2-3.5 \mu \mathrm{mol} / \mathrm{L})$ and DOM$1(0.2-228 \mu \mathrm{mol} / \mathrm{L})$ for additional $24 \mathrm{~h}$. A WST-1 assay was performed at the end of the experiment as explained earlier. Experiments were performed in three independent experiments.

\section{Albumin detection}

Albumin concentration in the undiluted supernatant was determined via colorimetric sandwich enzyme-linked immunosorbent assay (ELISA) (Abnova, Taiwan, China). Experiments were performed in duplicate in three independent experiments.

\section{LC-MS/MS analysis}

The RAW 264.7 cells were used as representative cell line to determine DOM-1 concentration after $24 \mathrm{~h}$ of incubation. Therefore, RAW cells were treated with RAW medium alone, DOM-1 $(1.74 \mu \mathrm{mol} / \mathrm{L})$ alone, and DOM-1 together with LPS $(1 \mu \mathrm{g} / \mathrm{mL})$ for $24 \mathrm{~h}$, frozen at $-80^{\circ} \mathrm{C}$, and then measured by liquid chromatography tandem mass spectrometry (LC-MS/ MS). Analyses were carried out on an Agilent 1100 series HPLC system (Waldbronn, Germany). Analytes were separat- ed in gradient elution on an Eclipse XDB-C8 column $(150 \times 4.6 \mathrm{~mm}, 5 \mu \mathrm{mol} / \mathrm{L})$ at $25^{\circ} \mathrm{C}$ using methanol $/ 5 \mathrm{mmol} /$ $\mathrm{L}$ aqueous ammonium acetate buffer (A 20/80, $v / v$; B 95/5, $v / v)$ as mobile phases. The gradient started with a linear increase from 0 to $100 \% \mathrm{~B}$ within $2 \mathrm{~min}$ and continued for $3 \mathrm{~min}$ at $100 \% \mathrm{~B}$. Afterwards, the column was re-equilibrated at $0 \%$ $\mathrm{B}$ for $2 \mathrm{~min}$, reaching a total run-time of $7 \mathrm{~min}$. The flow rate was $1 \mathrm{~mL} / \mathrm{min}$, and the injection volume was $15 \mu \mathrm{L}$.

Tandem mass spectrometric analysis was carried out on a 2000 QTrap mass spectrometer equipped with an APCI ion source (SCIEX) in the negative ionization mode. Parameters of selected reaction monitoring transitions (dwell time of $25 \mathrm{~ms}$ ) were optimized by software-controlled compound optimization and were as follows for DON and DOM- 1 that were determined in the form of their acetate adducts: DON quantifier $m / z 355.1 \rightarrow m / z 59.1$ (declustering potential (DP) $-16 \mathrm{~V}$, collision energy (CE) $-30 \mathrm{eV}$ ), DON qualifier $m / z 355.1 \rightarrow$ $\mathrm{m} / z, 265.1$ (DP $-16 \mathrm{~V}, \mathrm{CE}-12 \mathrm{eV}$ ); DOM-1 quantifier $\mathrm{m} / \mathrm{z}$ $339.1 \rightarrow m / z 59.1(\mathrm{DP}-21 \mathrm{~V}, \mathrm{CE}-40 \mathrm{eV})$, DOM-1 qualifier $m / z, 339.1 \rightarrow m / z 249.1(\mathrm{DP}-21 \mathrm{~V}, \mathrm{CE}-16 \mathrm{eV}$ ). Ion source settings were as follows: curtain gas $40 \mathrm{psi}$, source temperature $450{ }^{\circ} \mathrm{C}$, nebulizer gas (GS1) 15 psi, heater gas (GS2) $60 \mathrm{psi}$, and collisionally activated dissociation (CAD) gas 6 . Analyst ${ }^{\circledR}$ software version 1.5.2 was used for instrument control and data analysis.

Analytes were quantified on the basis of neat solvent calibration functions established between $10(\sim 0.03 \mu \mathrm{mol} / \mathrm{L})$ and $1000 \mathrm{ng} / \mathrm{mL}(\sim 3.57 \mu \mathrm{mol} / \mathrm{L})$ DOM-1. The retrieved DOM-1 was calculated as follows:

\section{Statistics}

Statistical analysis was performed with IBM® SPSS Statistics (Version 22.0, IBM Inc., New York, NY, USA, 2013). Values were analyzed for normality (Shapiro-Wilk) and homogeneity of variance (Levene Statistics). Normally distributed homogenous data were analyzed by analysis of variance (ANOVA) and Dunnett's $t$ test compared to those of the control. Normally distributed but not homogenous data were analyzed by ANOVA and Dunnett's T3-test. When the assumptions of the ANOVA were not met, a non-parametric Kruskal-Wallis test was used. Significances $(p<0.05)$ were marked with an asterisk.

Viability was calculated by setting the measured OD of the cell control to $100 \%$. When only three independent experiments were present, a joint mean, which was set to $100 \%$, was calculated.

\section{Results}

The viability of rainbow trout gill cells (RTgill-W1) was determined after treatment with equimolar amounts of DON and DOM-1 $(0.125-40 \mu \mathrm{mol} / \mathrm{L})$ with a SRB and NR assay. A significant effect of DON on cell viability was observed above $10 \mu \mathrm{mol} / \mathrm{L}(p=0.008)$ with the SRB assay and $20 \mu \mathrm{mol} / \mathrm{L}$ ( $p=0.002)$ with the NR assay. At the highest tested concentration $(40 \mu \mathrm{mol} / \mathrm{L})$, viability was reduced by $63 \% \pm 7.6$ $(p<0.001)$ and $52 \% \pm 5.0(p=0.018)$, according to the SRB and NR assay, respectively (Fig. 1).

However, no effect of DOM-1 on cell viability was detected for the range of concentrations tested.

We next assessed the effect of DON $(0.2-6.9 \mu \mathrm{mol} / \mathrm{L})$ and DOM-1 $(0.2-228 \mu \mathrm{mol} / \mathrm{L})$ on the viability of intestinal epithelial cell lines IPEC-1 and IPEC-J2 via the WST-1 assay. DON dose-dependently decreased viability in both cell lines 
Fig. 1 Effect of DON and DOM1 on viability (\%) of the RTgillW1 fish cell line. RTgill-W1 cells were treated with $\mathrm{DON}$ and DOM-1 (0.125-40 $\mu \mathrm{mol} / \mathrm{L})$ for $48 \mathrm{~h}$. A NR (sphere) and a SRB (square) assay were performed to assess the viability. Data represent mean $\pm \mathrm{SD}, n=3$ (NR) and $n=4$ (SRB). Asterisks indicate significant difference from control $(* p<0.05, * * p<0.01$, and $* * * p<0.001)$
RTgill-W1

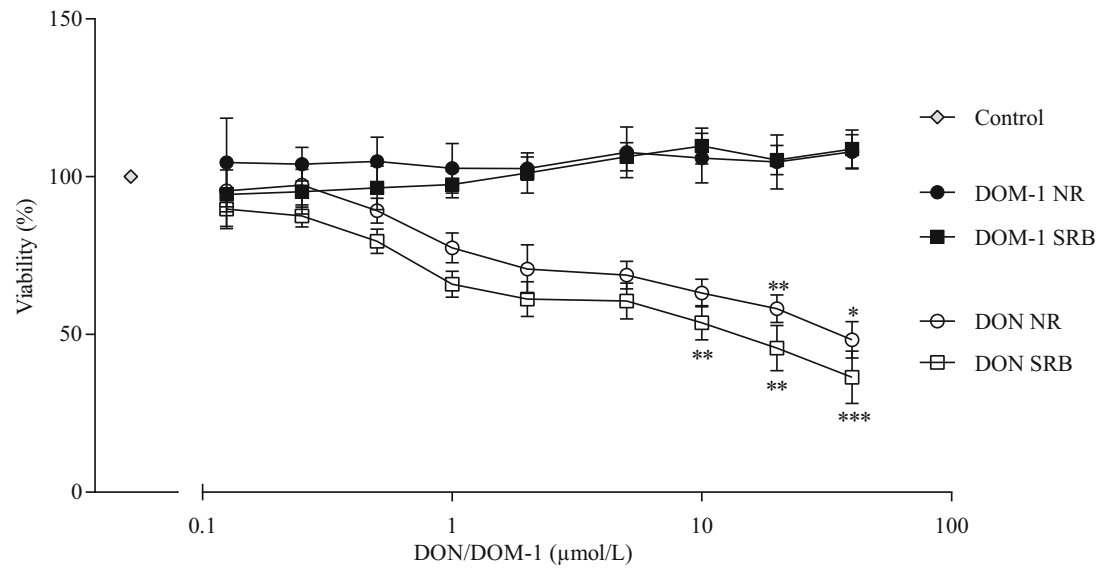

(Fig. 2). At concentrations at and above $0.9 \mu \mathrm{mol} / \mathrm{L} \mathrm{DON}$ (IPEC-1) and $3.5 \mu \mathrm{mol} / \mathrm{L}$ DON (IPEC-J2), a significant decrease $(p<0.05)$ in viability was observed. At the highest concentration $(6.9 \mu \mathrm{mol} / \mathrm{L} \mathrm{DON})$, viability of IPEC-1 and IPEC-J2 was reduced to $65.6 \% \pm 2.1$ and $60.9 \% \pm 8.3$, respectively. In contrast, DOM-1, even tested up to $228 \mu \mathrm{mol} / \mathrm{L}$, did not affect viability (>90\%) of either cell line at any tested concentration.

To further assess the effect of DON $(0.1-0.84 \mu \mathrm{mol} / \mathrm{L})$ and DOM-1 (1.78-28.5 $\mu \mathrm{mol} / \mathrm{L})$ on viability, NO, and cytokine release, the murine macrophage cell line RAW 264.7 was used with and without stimulation with LPS $(1 \mu \mathrm{g} / \mathrm{mL})$. LPS was used as a representative molecule to simulate inflammation. Inflammation is an important and vital tool to fight infections. The potential of DON or DOM-1 to suppress inflammatory processes was therefore assessed. Neither DON nor DOM-1 significantly decreased viability at the tested concentrations,

IPEC-1

a

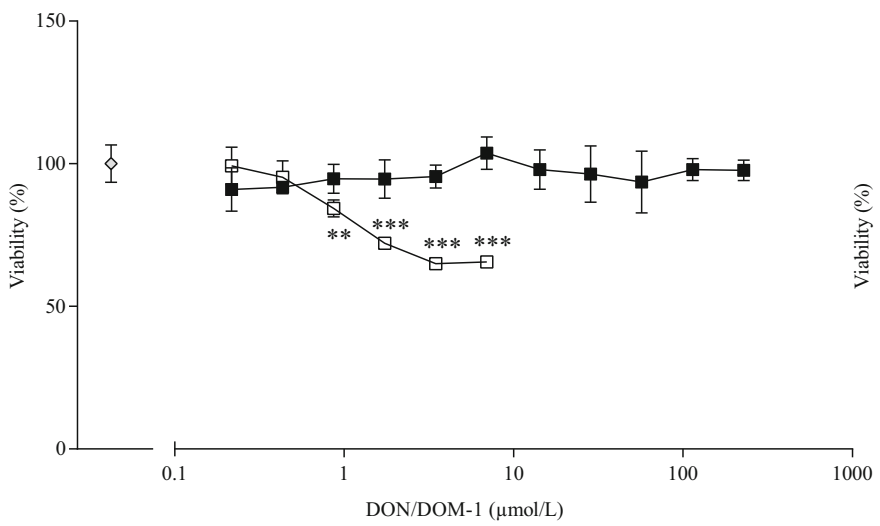

$\prec$ Control $\square$ DON

Fig. 2 Effect of DON and DOM-1 on viability (\%) of the IPEC-1 (left) and IPEC-J2 (right) cell line. a IPEC-1 and b IPEC-J2 were treated with DON $(0.2-6.9 \mu \mathrm{mol} / \mathrm{L})$ or DOM-1 $(0.2-228 \mu \mathrm{mol} / \mathrm{L})$ for $24 \mathrm{~h}$. Viability was evaluated with the WST-1 assay and expressed as relative values regardless of whether LPS was applied or not (Fig. 3a). Compared to untreated (control) cells, viability of LPSstimulated RAW 264.7 cells was increased by $49 \% \pm 24.0$. LPS treatment in the presence of DON or DOM-1 led to a similar $\sim 50 \%$ increase of viability.

NO release was induced neither by DON nor by DOM-1 at the tested concentrations in unstimulated cells (Fig. 3b). Values were at the level of the negative control $(5.4 \% \pm 8.0)$ for DON $(6.4 \% \pm 4.5)$ and DOM-1 $(4.9 \% \pm 2.4)$. However, in LPS-stimulated cells (set to $100 \%$ ), a significant decrease of NO release was observed at the highest DON concentration $(0.84 \mu \mathrm{mol} / \mathrm{L})(p=0.001)$, resulting in a decrease of $66.2 \% \pm 9.6$ compared to the LPS-induced NO production $(=100 \%)$. For DOM-1, no significant reduction even at higher concentrations was observed.

Additionally, supernatants were tested for IL- 6 and TNF- $\alpha$ cytokine release (Fig. 3c). DON and DOM-1 alone did not

b

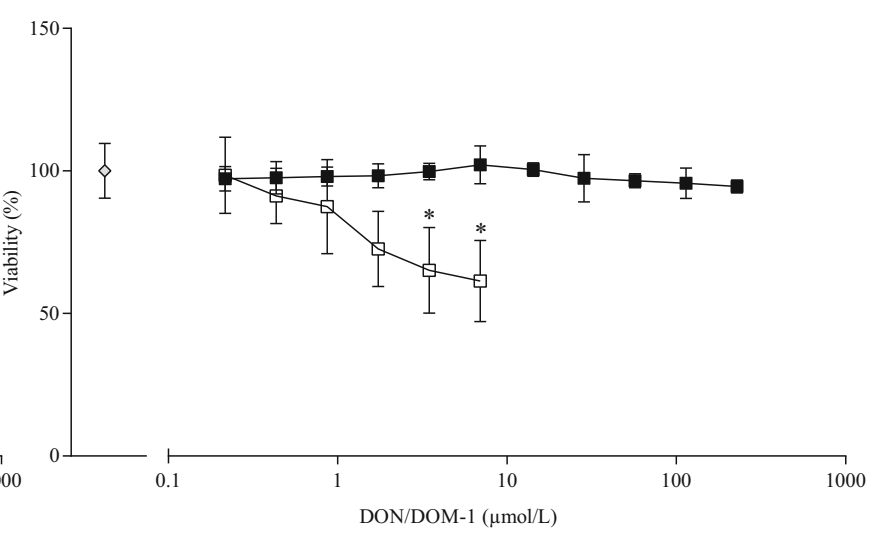

compared to the control of all independent experiments (set to a joint $100 \%$ ). Data represent mean $\pm \mathrm{SD}, n=3$. Asterisks indicate significant differences compared to control $(* p<0.05$, ** $p<0.01$, and $* * * p<0.001)$ 
Fig. 3 Effect of DON and DOM1 on a viability, b NO-, and c cytokine release of RAW 264.7 cells. RAW 264.7 cells were treated with DON $(0.1-$ $0.84 \mu \mathrm{mol} / \mathrm{L})$ or DOM-1 (1.78$28.5 \mu \mathrm{mol} / \mathrm{L})$ with $(+)$ and without (-) LPS $(1 \mu \mathrm{g} / \mathrm{mL})$ ( \pm LPS). After $24 \mathrm{~h}$ of incubation with the mycotoxin, a WST-1 assay was performed to assess viability (a) and the supernatant was collected for NO determination (b) and cytokine (IL-6 (triangle up) and TNF- $\alpha$ (triangle down) release (c). Data represent mean $\pm \mathrm{SD}, n=5$ (a and b), $n=3$ (c). Asterisks indicate significant differences from the respective control $(* * p<0.01$ and $* * * p<0.001)$
RAW 264.7
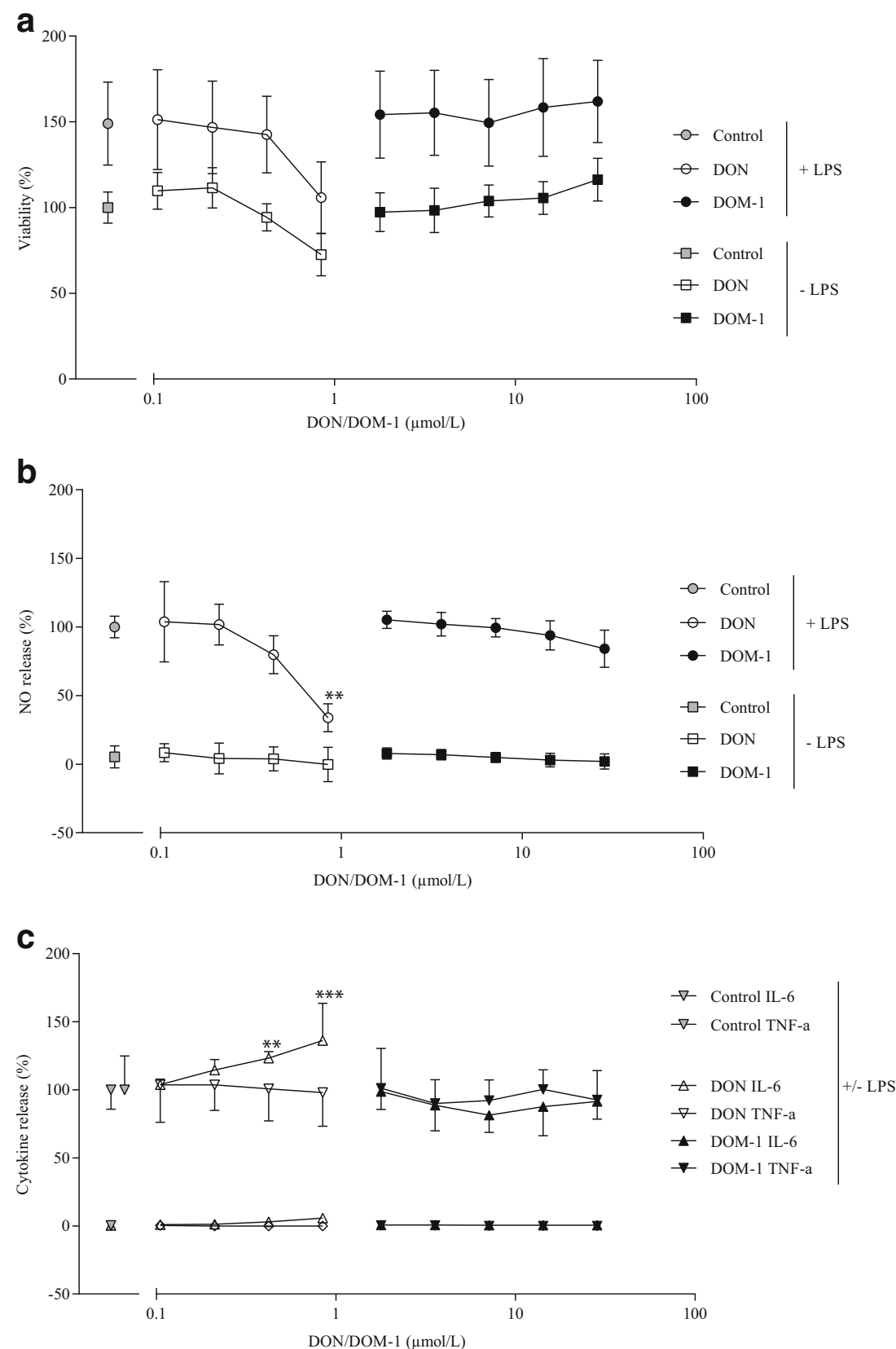

significantly affect cytokine release. Interestingly, a superinduction of the inflammatory cytokine IL-6 was observed in DON-treated cells stimulated with LPS. A significant increase of $23 \% \pm 4.8(p=0.008)$ was seen at $0.42 \mu \mathrm{mol} / \mathrm{L}$ and $36 \% \pm 27.4(p<0.001)$ at $0.84 \mu \mathrm{mol} / \mathrm{L}$ DON. In contrast, TNF- $\alpha$ levels for DON plus LPS-stimulated cells ranged between 98 and 103\%. DOM-1 in the presence of LPS did not influence the cytokine release for IL- 6 nor for TNF- $\alpha$.

HepG2 cells were stimulated with DON $(0.2-3.5 \mu \mathrm{mol} / \mathrm{L})$ and DOM-1 (0.2-228 $\mu \mathrm{mol} / \mathrm{L})$ for $24 \mathrm{~h}$, followed by a WST-1 assay. DON dose-dependently and significantly decreased viability at increasing concentrations starting at $0.9 \mu \mathrm{mol} / \mathrm{L}$ $(p<0.001)$ (Fig. 4). At the highest tested concentration of $3.5 \mu \mathrm{mol} / \mathrm{L} \mathrm{DON}$, viability was decreased by $39.7 \% \pm 4.0$. For DOM-1, no such effect was seen at even higher concentrations.

When albumin production was assessed in the respective supernatant, a similar trend was observed (Fig. 4). Albumin secretion was reduced by $47.3 \% \pm 10.3(p=0.02)$ at $0.9 \mu \mathrm{mol} /$ L DON. At $3.5 \mu \mathrm{mol} / \mathrm{L}$ DON, no more albumin was detected (99.6\% \pm 0.7 albumin reduction; $p=0.015)$. DOM-1 affected albumin production at the highest concentration $(228 \mu \mathrm{mol} /$ 


\section{HepG2}

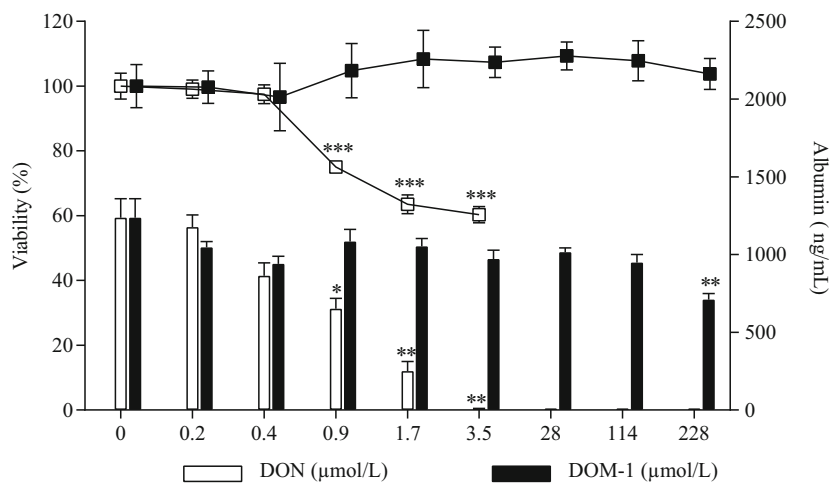

Fig. 4 Effect of DON and DOM-1 on viability (\%; left axis, squares) and albumin release (ng/mL; right axis, bars) of HepG2 cells. HepG2 cells were treated with either DON $(0.2-3.5 \mu \mathrm{mol} / \mathrm{L}$; white $)$ or DOM-1 $(0.2-$ $228 \mu \mathrm{mol} / \mathrm{L}$, black) for $24 \mathrm{~h}$. a Viability was assessed with a WST-1 assay after $24 \mathrm{~h}$ of incubation. b Albumin production was assessed via ELISA thereof. Data represent mean $\pm \mathrm{SD}, n=3$. Asterisks indicate significant difference from control $(* p<0.05, * * p<0.01$, and $* * * p<0.001)$

L), where a statistically significant reduction of $42.6 \% \pm 5.9$ $(p=0.002)$ was observed.

The stability of DON has been confirmed by many studies (reviewed in (Sobrova et al. 2010)). To assess the stability of DOM-1 in the course of the experiment, RAW 264.7 cells were treated with $1.74 \mu \mathrm{mol} / \mathrm{L}$ DOM-1 in the absence or presence of $1 \mu \mathrm{g} / \mathrm{mL}$ LPS for $24 \mathrm{~h}$. Supernatants were collected and measured by LC-MS/MS (Table 2). For all tested samples, the mean recovery rate was $98.9 \% \pm 2.4$ when DOM-1 was present. No DOM-1 was found in the respective medium control (RAW medium).

\section{Discussion}

The present study portrays the effects of DON and its primary microbial metabolite, DOM-1, on five different cell lines. In that, we are the first to provide the effects of DON and DOM-1 in cells of different species and tissue origin and report various degrees of sensitivity.

To compare effects of DON and DOM- 1 after $24 \mathrm{~h}$, viability was assessed with the WST-1 assay, targeting the mitochondrial activity, which, although less sensitive than other assays (Riss et al. 2004), provides a good correlation to in vivo data (Reubel et al. 1987). As the WST-1 assay was not valid for RTgill-W1 cells, most likely due to their low metabolic turnover and proliferation rate (Lee et al. 2009), viability was assessed with a dualparameter cytotoxicity assay for $48 \mathrm{~h}$, evaluating the lysosomal activity (NR assay) and total protein content (SRB assay). DON affected cell viability at concentrations above $0.9 \mu \mathrm{mol} / \mathrm{L}$ (IPEC1 and HepG2), $3.5 \mu \mathrm{mol} / \mathrm{L}$ (IPEC-J2), and $10 \mu \mathrm{mol} / \mathrm{L}$ (RTgill-W1). For RAW 264.7 cells, a lowered viability was observed in the presence of DON ( $\sim$ minus $30 \%$, regardless of the LPS stimulation) at the highest concentration $(0.84 \mu \mathrm{mol} / \mathrm{L}$ DON), which was, however, not significant. For further experiments, the DON concentration should therefore be increased. DOM-1 did not affect cell viability up to $228 \mu \mathrm{mol} / \mathrm{L}$. Significant effects on IL-6, NO-, and albumin release were already seen at lower DON concentrations of $0.42 \mu \mathrm{mol} / \mathrm{L}$ (IL-6), $0.84 \mu \mathrm{mol} / \mathrm{L}$ (NO), and $0.9 \mu \mathrm{mol} / \mathrm{L}$ (albumin). The only parameter affected by DOM-1 was albumin which was reduced by $\sim 50 \%$ at the highest tested concentration of $228 \mu \mathrm{mol} / \mathrm{L}$, demonstrating a $\sim 253$ times lower susceptibility to DOM-1 than to DON. This negative effect could be ascribed to the $0.1-0.2 \%$ DON contamination in the DOM-1 standard, which would already account for $0.23-0.46 \mu \mathrm{mol} / \mathrm{L}$ DON.

Mycotoxin-induced damage to gill cells - which are involved in gas exchange and osmoregulation and constitute the first line of defense in fish against pathogens and toxins - can lead to impairments of the whole organism. According to the recommendation of the European Commission (European Commission 2006), DON levels should not exceed $5 \mathrm{mg} / \mathrm{kg}$ in complete feedstuff for fish. In this study, $40 \mu \mathrm{mol} / \mathrm{L} \mathrm{DON}$ and equimolar DOM-1 concentrations were tested. RTgill-W1 were least sensitive to DON and viability was differently affected by DON, depending on the observed target. The total protein content (SRB assay) was already reduced at $10 \mu \mathrm{mol} / \mathrm{L} \mathrm{DON}$, whereas lysosomal activity (NR assay) was first affected at $20 \mu \mathrm{mol} / \mathrm{L}$. The higher sensitivity of the SRB assay has been recently shown by Springler et al. (2016a) and can be explained by the primary toxicological feature of DON, protein synthesis impairment (Springler et al. 2016a). These negative effects of DON could already be seen at $2 \mu \mathrm{mol} / \mathrm{L} \mathrm{DON}$, where a viability reduction of $39 \% \pm 3.6$ was observed. Our findings are in accordance with Pietsch et al. (2011), who confirmed reduced viabilities at concentrations above $2.7 \mu \mathrm{mol} / \mathrm{L}$ DON for both applied assays.
Table 2 Recovery rate of DOM$1(\%)$ measured by LC-MS/MS after $24 \mathrm{~h}$ of incubation. Data represent mean $\pm \mathrm{SD}, n=3$

\begin{tabular}{llll}
\hline Sample & \multicolumn{2}{l}{ Retrieved DOM-1 } & Incubation time \\
\cline { 2 - 3 } & $(\mu \mathrm{mol} / \mathrm{L})$ & $(\%)$ & \\
\hline DOM-1 $(1.74 \mu \mathrm{mol} / \mathrm{L})$ & $1.75 \pm 0.07$ & $100.6 \pm 4.0$ & $24 \mathrm{~h}$ \\
DOM-1 $(1.74 \mu \mathrm{mol} / \mathrm{L})+$ LPS $(1 \mu \mathrm{g} / \mathrm{mL})$ & $1.69 \pm 0.07$ & $97.1 \pm 4.0$ & \\
RAW medium & No peak & 0 & \\
Recovery rate $($ mean $\pm \mathrm{SD})$ & & $98.9 \pm 2.4$ & \\
\hline
\end{tabular}


Living rainbow trout were even more sensitive to DON, as weight gain, feed intake, and feed efficiency were already affected by $0.5 \mathrm{mg} / \mathrm{kg}$ DON in feed (Hooft et al. 2011). DOM-1 has never been studied in fish - we are the first to provide insight into the non-cytotoxic effects of DOM-1 on fish cells up to $40 \mu \mathrm{mol} / \mathrm{L}$.

IPEC-1 and IPEC-J2 are already established models to thoroughly study the intestinal function, especially due to their morphological and functional constitution, as well as their sensitivity to toxins (Nossol et al. 2011). Concentrations up to $6.9 \mu \mathrm{mol} / \mathrm{L} \mathrm{DON}$ were used, which would correspond to $2 \mathrm{mg} / \mathrm{kg}$ DON in feed according to the calculations of Pinton et al. (2010). A decrease in viability was observed at DON concentrations above $0.9 \mu \mathrm{mol} / \mathrm{L}$ DON for IPEC-1 and $3.5 \mu \mathrm{mol} / \mathrm{L}$ for IPEC-J2, suggesting that IPEC-1 are more sensitive to DON. This is in accordance with Dänicke et al. (2010), where a significant decrease in viability was seen at $0.2 \mu \mathrm{mol} / \mathrm{L}$ DON for IPEC-1 and $0.7 \mu \mathrm{mol} / \mathrm{L}$ DON for IPECJ2 assessed by MTT assay (Dänicke et al. 2010). In contrast to our study, DON was added directly after cell seeding and for $24 \mathrm{~h}$ longer, explaining the higher sensitivity of the cells. In a study of Alassane-Kpembi et al. (2015), reduced viability was seen above $0.5 \mu \mathrm{mol} / \mathrm{L}$ DON with the MTT assay in IPEC-1 (Alassane-Kpembi et al. 2015), which is in accordance to our results. For DOM-1, no decrease in viability was seen, although more than 32 times higher concentrations (up to $228 \mu \mathrm{mol} / \mathrm{L}$ DOM-1) compared to DON were used.

To apply and correlate in vitro to in vivo results, the exposure of the cells has to be taken into account. Intestinal cells in vivo are not permanently subjected to DON, but exposed at time-dependent fluctuations. Orally ingested DON reaches a maximum after $30 \mathrm{~min}$ in the plasma, whereas the absorption phase is nearly finished $4 \mathrm{~h}$ after DON ingestion (Dänicke et al. 2010; Goyarts and Dänicke 2006). In contrast, the intestinal cell lines are permanently exposed to DON for $24 \mathrm{~h}$, without the protective mucus layer, explaining toxic effects already at lower concentrations compared to in vivo results. A similar decrease in viability was also observed in other cell lines, such as the human intestinal HT-29-D4 cells (Maresca et al. 2002) with a viability decrease at $1 \mu \mathrm{mol} / \mathrm{L}$ DON. In the human adenocarcinoma cell line Caco-2, a decrease of viability was observed at $0.7 \mu \mathrm{mol} / \mathrm{L}$ (Sergent et al. 2006), $3.4 \mu \mathrm{mol} / \mathrm{L}$ (Cetin and Bullerman 2005), and $1.38 \mu \mathrm{mol} / \mathrm{L}$ (He et al. 2015), which is in accordance to our results.

In serum, DON can affect blood cells such as macrophages. A comparable and linear relationship between DON consumption and retrieval in blood has been reported by Döll et al. (2003) and Dänicke et al. (2004a, b). DON concentrations up to $100 \mathrm{ng} / \mathrm{mL}$ ( $\sim 0.3 \mu \mathrm{mol} / \mathrm{L})$ (Coppock et al. 1985) and $325 \mathrm{ng} / \mathrm{mL}(\sim 1 \mu \mathrm{mol} /$ L) (Prelusky et al. 1988) were detected. The macrophage cell line RAW 264.7 was chosen for assessing effects of DON on blood cells. In this study, DON either enhanced (IL-6 increase) or suppressed (decrease in $\mathrm{NO}$ release) critical macrophage functions. While mediators, such as NO, play a key role in immunity, vasodilation, inflammation, thrombosis, and neurotransmission (Fukuo et al. 1995), it also has been shown that activated macrophages suppress the NO release and simultaneously increase the release of the pro-inflammatory cytokines (e.g., TNF- $\alpha$ and IL-6) (Ji et al. 1998). According to Shi et al. (2009), low and moderate DON exposure induced pro-inflammatory gene expression, but repeated exposures to high concentrations induced cell death (Shi et al. 2009). In this study, the viability of DON-treated RAW 264.7 cells was not significantly decreased at the tested concentrations, even though a reduction of $27 \%$ for unstimulated and $44 \%$ for stimulated cells was seen. Vandenbroucke et al. (2009) saw significant reduction in viability $(-15 \%)$ already at $0.84 \mu \mathrm{mol} / \mathrm{L} \mathrm{DON}$ in porcine macrophages (Vandenbroucke et al. 2009). For DOM-1, no viability reduction was observed in our study, neither with nor without LPS stimulation, even though $\sim 34$ times higher concentrations were used. Protein synthesis inhibitors, like anisomycin and cycloheximide, or DON, have been shown to superinduce cytokine gene expression and secretion (Ghareeb et al. 2015). The phenomenon of superinduction is not fully understood yet but can partially be explained by a decreased messenger RNA (mRNA) degradation through inhibition of translational repressor proteins, a decreased synthesis of labile selective nucleases (Azcona-Olivera et al. 1995), or a direct stimulation of intracellular signaling pathways (Mahadevan and Edwards 1991). In RAW 264.7 cells, TNF-a and IL-6 superinduction has been observed after DON exposure (Ji et al. 1998, Zhou et al. 1999). Wong et al. (1998) however, only detected IL-6 but not TNF-a superinduction (Wong et al. 1998). This could be explained by the increased half-life for IL-6 mRNA (60 min) compared to TNF-a mRNA (25 min) — which was even further increased in the presence of DON $(\sim 0.84 \mu \mathrm{mol} / \mathrm{L})$ (Wong et al. 2001), as well as the increased stability of IL-6 (24 h) compared to TNF-a (6 h) (Sugita-Konishi and Pestka 2001).

When cytotoxicity ofDON was assessed in HepG2 cells, a decrease in viability was already observed at $0.9 \mu \mathrm{mol} / \mathrm{L}$. These liver cells seem to be as sensitive as the IPEC-1 cell line in these experiments. Other studies that assessed the effect on DON on HepG2 cells found varying IC50 values of $1.9 \mu \mathrm{mol} / \mathrm{L}$ (Nielsen et al. 2009a), $1.89 \mu \mathrm{mol} / \mathrm{L}$ (Nielsen et al. 2009b), and $28.2 \mu \mathrm{mol} / \mathrm{L}$ after $48 \mathrm{~h}$ of incubation (Cetin and Bullerman 2005). Nielsen et al. (2009b) observed a viability reduction of $25 \%$ at $1 \mu \mathrm{mol} / \mathrm{L} \mathrm{DON}$ which is in accordance to our observation $(24.9 \% \pm 1$ reduction at $0.9 \mu \mathrm{mol} / \mathrm{L}$ DON). When albumin release was assessed in the respective supernatant, a similar picture compared to the toxic effect of DON was observed. A significant decrease was observed at $0.9 \mu \mathrm{mol} / \mathrm{L}$. Interestingly, albumin was the only parameter that was affected by DOM-1. However, the concentration of $228 \mu \mathrm{mol} / \mathrm{L}$ DOM-1 was comparatively high and would correspond to $68 \mathrm{mg} / \mathrm{kg}$ DON in the feed, according to the calculation of Pinton et al. (2010). The effect cannot be explained by DON contamination of the DOM-1 standard, which was evaluated by LC-MS/MS. 
Animals with a high bacterial load at the upper part of the gastrointestinal tract (such as ruminants with bacteria in rumen and birds with bacteria in the crop) are able to bacterially biotransform DON into less toxic metabolites, such as DOM-1, leaving the animal less affected by the toxin. In monogastric animals (e.g., humans/pigs/rodents) however, ingested DON can directly enter the blood crossing the intestinal epithelium. In these animals, detoxification strategies, such as intestinal biotransformation, were predominately observed in the lower gastrointestinal tract, hence only marginal detoxification is possible by bacterial transformation (Maresca 2013). With the use of feed additives that contain DON- to DOM-1-transforming bovine rumen bacteria, such as Genus novus (formerly Eubacterium) species novus BBSH 797 of the Coriobacteriaceae family, DOM-1 gains relevance in feed again and food safety has to be assured (European Commission 2013). The mode of action of the deepoxidation of DON was proven in in vitro and in vivo experiments (Ghareeb et al. 2015; Schatzmayr et al. 2006).

For DOM-1, studies on the cytotoxic effect are scarce. Kollarczik et al. (1994) were the first to show that the metabolite, biotransformed in the bowel after anaerobic incubation with DON, significantly decreased the cytotoxicity of DON in pig kidney cells. Although some studies regarding the effects of DOM-1 are available (Dänicke et al. 2011; Mishra et al. 2014; Nasri et al. 2006; Sundstol Eriksen et al. 2004), a thorough comparison of five different cell lines has never been conducted. Additionally, the stability of DOM-1 via LC-MS/MS has never been assessed before.

Although susceptibility to DON varies between animal species, which can be explained by differences in absorption, metabolism, and elimination of DON (Pestka 2010; Pestka and Smolinski 2005) as well as in differences in the location of bacteria, susceptibility can also vary greatly among cell types. A direct transfer of results from in vitro to in vivo is therefore always challenging.

This study provides, for the first time, effects of DON and DOM-1 on five different cell lines of different animal origin, starting from the first line of defense, the gill and intestinal cells over immune cells to liver cells. Overall, DON reduced viability in RTgill-W1 $(10 \mu \mathrm{mol} / \mathrm{L})$, IPEC1 (above $0.9 \mu \mathrm{mol} / \mathrm{L}$ ), IPEC-J2 (above $3.5 \mu \mathrm{mol} / \mathrm{L}$ ), and HepG2 cells (above $0.9 \mu \mathrm{mol} / \mathrm{L}$ ), whereas DOM-1 did not have such an effect. The cell parameter that was affected by the lowest DON concentration of $0.42 \mu \mathrm{mol} / \mathrm{L} \mathrm{DON}$ in LPS-stimulated RAW 264.7 cells was IL-6, followed by the NO release at $0.84 \mu \mathrm{mol} / \mathrm{L}$ in LPS-stimulated RAW 264.7 cells. Albumin secretion of HepG2 cells was the only parameter decreased by both, DON and DOM-1, but at a much higher concentration for DOM-1 (228 versus $0.9 \mu \mathrm{mol} / \mathrm{L}$ for $\mathrm{DON})$.
Acknowledgements We especially thank Ryan Hines for proofreading the manuscript and Nora Schauerhuber, Katharina Botzi, Julia Panhölzl, and Carina Kalteis for the support in the laboratory.

Compliance with ethical standards The founding sponsors had no role in the design of the study; in the collection, analyses, or interpretation of data; in the writing of the manuscript; and in the decision to publish the results. All experiments comply with the current Austrian laws.

Source of funding The authors would like to thank the Austrian Research Promotion Agency (FFG) for funding this study (grant numbers 848211 and 839107). In addition, the authors thank the Austrian Federal Ministry of Economy, Family and Youth and the National Foundation for Research, Technology and Development for funding the Christian Doppler Laboratory for Mycotoxin Metabolism.

\section{Conflict of interest The authors declare no conflict of interest.}

Open Access This article is distributed under the terms of the Creative Commons Attribution 4.0 International License (http:// creativecommons.org/licenses/by/4.0/), which permits unrestricted use, distribution, and reproduction in any medium, provided you give appropriate credit to the original author(s) and the source, provide a link to the Creative Commons license, and indicate if changes were made.

\section{References}

Alassane-Kpembi I, Puel O, Oswald IP (2015) Toxicological interactions between the mycotoxins deoxynivalenol, nivalenol and their acetylated derivatives in intestinal epithelial cells. Arch Toxicol 89:13371346. doi:10.1007/s00204-014-1309-4

Anater AS, Manyes L, Meca G, Ferrer E, Bittencourt Luciano F, Pimpão CT, Font G (2016) Mycotoxins and their consequences in aquaculture: a review aquaculture 451:1-10 doi:10.1016/j.aquaculture. 2015.08.022

Azcona-Olivera JI, Ouyang YL, Warner RL, Linz JE, Pestka JJ (1995) Effects of vomitoxin (deoxynivalenol) and cycloheximide on IL-2, 4, 5 and 6 secretion and mRNA levels in murine CD4+ cells Food Chem Toxicol 33:433-441 doi:027869159500012Q

Bols NC, Barlian A, Chirino-Trejo M, Caldwell SJ, Goegan P, Lee LEJ (1994) Development of a cell line from primary cultures of rainbow trout, Oncorhynchus mykiss (Walbaum), gills. J Fish Dis:601-611 doi:10.1111/j.1365-2761

Broekaert N, Devreese M, van Bergen T, Schauvliege S, De Boevre M, De Saeger S, Vanhaecke L, Berthiller F, Michlmayr H, Malachová A, Adam G, Vermeulen A, Croubels S (2016) In vivo contribution of deoxynivalenol-3-beta-D-glucoside to deoxynivalenol exposure in broiler chickens and pigs: oral bioavailability, hydrolysis and toxicokinetics. Arch Toxicol 91(2):699-712. doi:10.1007/s00204$016-1710-2$

CAST (2013) Mycotoxins: risks in plant, animal, and human systems vol 139 Ames, Iowa

Cetin Y, Bullerman LB (2005) Cytotoxicity of Fusarium mycotoxins to mammalian cell cultures as determined by the MTT bioassay Food Chem Toxicol 43:755-764 doi:S0278-6915(05)00048-7

Coppock RW, Swanson SP, Gelberg HB, Koritz GD, Hoffman WE, Buck WB, Vesonder RF (1985) Preliminary study of the pharmacokinetics and toxicopathy of deoxynivalenol (vomitoxin) in swine. Am J Vet Res 46:169-174

D'Mello JPF, Placinta CM, Macdonald AM (1999) Fusarium mycotoxins: a review of global implications for animal health, welfare 
and productivity Animal Feed Science and Technology 80:183-205 doi:10.1016/S0377-8401(99)00059-0

Dänicke S, Goyarts T, Valenta H, Razzazi E, Böhm J (2004a) On the effects of deoxynivalenol (DON) in pig feed on growth performance, nutrients utilization and DON metabolism Journal of Animal and Feed Sciences 13:539-556 doi:10.22358/jafs/67624/2004

Dänicke S, Valenta H, Döll S (2004b) On the toxicokinetics and the metabolism of deoxynivalenol (DON) in the pig. Arch Anim Nutr 58:169-180. doi:10.1080/00039420410001667548

Dänicke S, Hegewald AK, Kahlert S, Kluess J, Rothkötter HJ, Breves G, Döll S (2010) Studies on the toxicity of deoxynivalenol (DON), sodium metabisulfite, DON-sulfonate (DONS) and de-epoxyDON for porcine peripheral blood mononuclear cells and the intestinal porcine epithelial cell lines IPEC-1 and IPEC-J2, and on effects of DON and DONS on piglets Food Chem Toxicol 48:2154-2162 doi:10.1016/j.fct.2010.05.022

Dänicke S, Keese C, Goyarts T, Döll S (2011) Effects of deoxynivalenol (DON) and related compounds on bovine peripheral blood mononuclear cells (PBMC) in vitro and in vivo. Mycotoxin Res 27:49-55. doi:10.1007/s12550-010-0074-3

Dirican S (2015) A review of effects of aflatoxins in aquaculture Applied Research Journal 1:192-196

Döll S, Dänicke S, Ueberschär KH, Valenta H, Schnurrbusch U, Ganter M, Klobasa F, Flachowsky G (2003) Effects of graded levels of Fusarium toxin contaminated maize in diets for female weaned piglets. Arch Tierernahr 57:311-334

Döll S, Dänicke S, Valenta H (2008) Residues of deoxynivalenol (DON) in pig tissue after feeding mash or pellet diets containing low concentrations. Mol Nutr Food Res 52:727-734. doi:10.1002/mnfr. 200700308

EFSA (2013a) Scientific opinion on the safety and efficacy of microorganism DSM 11798 when used as a technological feed additive for pigs EFSA J 11:3203

EFSA (2013b) Deoxynivalenol in food and feed: occurrence and exposure EFSA J 11:319-324

Ehrlich KC, Daigle KW (1987) Protein synthesis inhibition by 8-oxo-12, 13-epoxytrichothecenes Biochim Biophys Acta 923:206-213 doi: 0304-4165(87)90005-5

European Commission (EC) (2006) Commission Recommendation of 17 August 2006 on the presence of deoxynivalenol, zearalenone, ochratoxin A, T-2 and HT-2 and fumonisins in products intended for animal feeding (2006/576/EU) vol L 229

European Commission (EC) (2013) Commission implementing regulation (EU) No 1016/2013 of 23 October 2013 concerning the authorisation of a preparation of mico-organism strain DSM 11798 of the Coriobacteriacae family as a feed additive for pigs. Off J Eur Union, L282/36

Fry JP, Love DC, MacDonald GK, West PC, Engstrom PM, Nachman KE, Lawrence RS (2016) Environmental health impacts of feeding crops to farmed fish. Environ Int 91:201-214. doi:10.1016/j.envint. 2016.02.022

Fuchs E, Binder EM, Heidler D, Krska R (2002) Structural characterization of metabolites after the microbial degradation of type A trichothecenes by the bacterial strain BBSH 797 Food Addit Contam 19: 379-386 doi:10.1080/02652030110091154

Fukuo K, Inoue T, Morimoto S, Nakahashi T, Yasuda O, Kitano S, Sasada R, Ogihara T (1995) Nitric oxide mediates cytotoxicity and basic fibroblast growth factor release in cultured vascular smooth muscle cells. A possible mechanism of neovascularization in atherosclerotic plaques. J Clin Invest 95:669-676. doi:10.1172/JCI117712

Ghareeb K, Awad WA, Bohm J, Zebeli Q (2015) Impacts of the feed contaminant deoxynivalenol on the intestine of monogastric animals: poultry and swine. J Appl Toxicol 35:327-337. doi:10.1002/jat.3083

Gonçalves R, Naehrer K, Santos GA (2016) Occurrence of mycotoxins in commercial aquafeeds in Asia and Europe: a real risk to aquaculture? Aquaculture doi:http://dx.Doi.Org/10.1111/raq.12159
Gonzalez-Vallina R, Wang H, Zhan R, Berschneider HM, Lee RM, Davidson NO, Black DD (1996) Lipoprotein and apolipoprotein secretion by a newborn piglet intestinal cell line (IPEC-1). Am J Phys 271:G249-G259

Goyarts T, Dänicke S (2006) Bioavailability of the Fusarium toxin deoxynivalenol (DON) from naturally contaminated wheat for the pig Toxicol Lett 163:171-182 doi:S0378-4274(05)00344-9

Greco M, Pardo A, Pose G (2015) Mycotoxigenic fungi and natural cooccurrence of mycotoxins in rainbow trout (Oncorhynchus mykiss) feeds Toxins (Basel) 7:4595-4609doi:10.3390/toxins 7114595

Grenier B, Applegate TJ (2013) Modulation of intestinal functions following mycotoxin ingestion: meta-analysis of published experiments in animals. Toxins (Basel) 5:396-430. doi:10.3390/ toxins5020396

He JW, Bondy GS, Zhou T, Caldwell D, Boland GJ, Scott PM (2015) Toxicology of 3-epi-deoxynivalenol, a deoxynivalenoltransformation product by Devosia mutans 17-2-E-8 Food Chem Toxicol 84:250-259 doi:10.1016/j.fct.2015.09.003

Hoerger CC, Schenzel J, Strobel BW, Bucheli TD (2009) Analysis of selected phytotoxins and mycotoxins in environmental samples. Anal Bioanal Chem 395:1261-1289. doi:10.1007/s00216-009-3088-y

Hooft JM, Elmor AEHI, Encarnação P, Bureau DP (2011) Rainbow trout (Oncorhynchus mykiss) is extremely sensitive to the feed-borne Fusarium mycotoxin deoxynivalenol (DON). Aquaculture 311: 224-232. doi:10.1016/j.aquaculture.2010.11.049

Ji GE, Park SY, Wong SS, Pestka JJ (1998) Modulation of nitric oxide, hydrogen peroxide and cytokine production in a clonal macrophage model by the trichothecene vomitoxin (deoxynivalenol). Toxicology 125:203-214

Kollarczik B, Gareis M, Hanelt M (1994) In vitro transformation of the Fusarium mycotoxins deoxynivalenol and zearalenone by the normal gut microflora of pigs. Nat Toxins 2:105-110

Lee LEJ, Dayeh VR, Schirmer K, Bols NC (2009) Applications and potential uses of fish gill cell lines: examples with RTgill-W1. In Vitro Cell Dev Biol Anim 45:127-134

Lorsbach RB, Murphy WJ, Lowenstein CJ, Snyder SH, Russell SW (1993) Expression of the nitric oxide synthase gene in mouse macrophages activated for tumor cell killing. Molecular basis for the synergy between interferon-gamma and lipopolysaccharide. J Biol Chem 268:1908-1913

Mahadevan LC, Edwards DR (1991) Signalling and superinduction. Nature 349:747-748. doi:10.1038/349747c0

Maresca M (2013) From the gut to the brain: journey and pathophysiological effects of the food-associated trichothecene mycotoxin deoxynivalenol Toxins (Basel) 5:784-820 doi:10.3390/ toxins5040784

Maresca M, Mahfoud R, Garmy N, Fantini J (2002) The mycotoxin deoxynivalenol affects nutrient absorption in human intestinal epithelial cells. J Nutr 132:2723-2731

McCormick SP (2013) Microbial detoxification of mycotoxins. J Chem Ecol 39:907-918. doi:10.1007/s10886-013-0321-0

Mishra S, Dixit S, Dwivedi PD, Pandey HP, Das M (2014) Influence of temperature and $\mathrm{pH}$ on the degradation of deoxynivalenol (DON) in aqueous medium: comparative cytotoxicity of DON and degraded product. Food Addit Contam Part A Chem Anal Control Expo Risk Assess 31:121-131. doi:10.1080/19440049.2013.861613

Nagl V, Woechtl B, Schwartz-Zimmermann HE, Hennig-Pauka I, Moll WD, Adam G, Berthiller F (2014) Metabolism of the masked mycotoxin deoxynivalenol-3-glucoside in pigs Toxicol Lett 229:190197 doi:10.1016/j.toxlet.2014.06.032

Nasri T, Bosch RR, Voorde S, Fink-Gremmels J (2006) Differential induction of apoptosis by type A and B trichothecenes in Jurkat T-lymphocytes Toxicol In Vitro 20:832-840 doi:S0887-2333(06)00006-3

Nielsen C, Casteel M, Didier A, Dietrich R, Martlbauer E (2009a) Trichothecene-induced cytotoxicity on human cell lines. Mycotoxin Res 25:77-84. doi:10.1007/s12550-009-0011-5 
Nielsen C, Lippke H, Didier A, Dietrich R, Martlbauer E (2009b) Potential of deoxynivalenol to induce transcription factors in human hepatoma cells. Mol Nutr Food Res 53:479-491. doi:10.1002/mnfr. 200800475a

Nossol C, Diesing AK, Walk N, Faber-Zuschratter H, Hartig R, Post A, Kluess J, Rothkötter HJ, Kahlert S (2011) Air-liquid interface cultures enhance the oxygen supply and trigger the structural and functional differentiation of intestinal porcine epithelial cells (IPEC). Histochem Cell Biol 136:103-115. doi:10.1007/s00418-011-0826-y

Pelyhe C, Kovesi B, Zandoki E, Kovacs B, Szabo-Fodor J, Mezes M, Balogh K (2016) Effect of 4-week feeding of deoxynivalenol- or T2-toxin-contaminated diet on lipid peroxidation and glutathione redox system in the hepatopancreas of common carp (Cyprinus carpio L.) Mycotoxin Res 32(2):77-83. doi:10.1007/s12550-016-0242-1

Pestka JJ (2010) Deoxynivalenol: mechanisms of action, human exposure, and toxicological relevance. Arch Toxicol 84:663-679. doi:10. 1007/s00204-010-0579-8

Pestka JJ, Smolinski AT (2005) Deoxynivalenol: toxicology and potential effects on humans. J Toxicol Environ Health B Crit Rev 8:39-69. doi:10.1080/10937400590889458

Pestka JJ, Zhou HR, Moon Y, Chung YJ (2004) Cellular and molecular mechanisms for immune modulation by deoxynivalenol and other trichothecenes: unraveling a paradox. Toxicol Lett 153:61-73. doi: 10.1016/j.toxlet.2004.04.023

Pietsch C, Bucheli TD, Wettstein FE, Burkhardt-Holm P (2011) Frequent biphasic cellular responses of permanent fish cell cultures to deoxynivalenol (DON). Toxicol Appl Pharmacol 256:24-34. doi: 10.1016/j.taap.2011.07.004

Pietsch C, Katzenback BA, Garcia-Garcia E, Schulz C, Belosevic M, Burkhardt-Holm P (2015) Acute and subchronic effects on immune responses of carp (Cyprinus carpio L.) after exposure to deoxynivalenol (DON) in feed. Mycotoxin Res 31(3):151-164. doi:10.1007/s12550-015-0226-6

Pinton P, Braicu C, Nougayrede JP, Laffitte J, Taranu I, Oswald IP (2010) Deoxynivalenol impairs porcine intestinal barrier function and decreases the protein expression of claudin-4 through a mitogenactivated protein kinase-dependent mechanism J Nutr 140:19561962 doi:10.3945/jn.110.123919

Pinton P, Tsybulskyy D, Lucioli J, Laffitte J, Callu P, Lyazhri F, Grosjean F, Bracarense AP, Kolf-Clauw M, Oswald IP (2012) Toxicity of deoxynivalenol and its acetylated derivatives on the intestine: differential effects on morphology, barrier function, tight junction proteins, and mitogen-activated protein kinases Toxicol Sci 130:180190 doi:10.1093/toxsci/kfs239kfs239

Prelusky DB, Hartin KE, Trenholm HL, Miller JD (1988) Pharmacokinetic fate of 14C-labeled deoxynivalenol in swin. Fundam Appl Toxicol 10:276-286e

Reubel GH, Gareis M, Amselgruber WM (1987) Cytotoxicity evaluation of mycotoxins by an MTT-bioassay. Mycotoxin Res 3:85-96. doi: 10.1007/BF03191994

Riss TL, Moravec RA, Niles AL, Duellman S, Benink HA, Worzella TJ, Minor L (2004) Cell viability assays doi:NBK144065

Savard C, Gagnon CA, Chorfi Y (2015) Deoxynivalenol (DON) naturally contaminated feed impairs the immune response induced by porcine reproductive and respiratory syndrome virus (PRRSV) live attenuated vaccine. Vaccine 33:3881-3886. doi:10.1016/j.vaccine.2015.06.069

Schatzmayr G, Streit E (2013) Global occurrence of mycotoxins in the food and feed chain: facts and figures. World Mycotoxin Journal 6: 213-222. doi:10.3920/WMJ2013.1572

Schatzmayr G, Zehner F, Taubel M, Schatzmayr D, Klimitsch A, Loibner AP, Binder EM (2006) Microbiologicals for deactivating mycotoxins. Mol Nutr Food Res 50:543-551. doi:10.1002/mnfr.200500181

Schierack P, Nordhoff M, Pollmann M, Weyrauch KD, Amasheh S, Lodemann U, Jores J, Tachu B, Kleta S, Blikslager A, Tedin K,
Wieler LH (2006) Characterization of a porcine intestinal epithelial cell line for in vitro studies of microbial pathogenesis in swine. Histochem Cell Biol 125:293-305. doi:10.1007/s00418-005-0067-z

Schwartz-Zimmermann HE, Fruhmann P, Dänicke S, Wiesenberger G, Caha S, Weber J, Berthiller F (2015) Metabolism of deoxynivalenol and deepoxy-deoxynivalenol in broiler chickens, pullets, roosters and turkeys Toxins (Basel) 7:4706-4729 doi:10.3390/ toxins 7114706

Sergent T, Parys M, Garsou S, Pussemier L, Schneider YJ, Larondelle Y (2006) Deoxynivalenol transport across human intestinal Caco-2 cells and its effects on cellular metabolism at realistic intestinal concentrations Toxicol Lett 164:167-176 doi:S0378-4274(05)00425-X

Shi Y, Porter K, Parameswaran N, Bae HK, Pestka JJ (2009) Role of GRP78/BiP degradation and ER stress in deoxynivalenol-induced interleukin-6 upregulation in the macrophage Toxicol Sci 109:247255 doi:10.1093/toxsci/kfp060kfp060

Sobrova P, Adam V, Vasatkova A, Beklova M, Zeman L, Kizek R (2010) Deoxynivalenol and its toxicity. Interdiscip Toxicol 3:94-99. doi:10. 2478/v10102-010-0019-x

Springler A, Hessenberger S, Reisinger N, Kern C, Nagl V, Schatzmayr G, Mayer E (2016a) Deoxynivalenol and its metabolite deepoxydeoxynivalenol:multi-parameter analysis for the evaluation of cytotoxicity and cellular effects. Mycotoxin Res. doi:10.1007/s12550-016-0260-Z

Springler A, Hessenberger S, Schatzmayr G, Mayer E (2016b) Early activation of MAPK p44/42 is partially involved in DON-induced disruption of the intestinal barrier function and tight junction network Toxins (Basel) 8doi:10.3390/toxins8090264

Sugita-Konishi Y, Pestka JJ (2001) Differential upregulation of TNF-alpha, IL-6, and IL-8 production by deoxynivalenol (vomitoxin) and other 8-ketotrichothecenes in a human macrophage model. J Toxicol Environ Health A 64(8):619-636

Sundstol Eriksen G, Pettersson H, Lundh T (2004) Comparative cytotoxicity of deoxynivalenol, nivalenol, their acetylated derivatives and de-epoxy metabolites Food Chem Toxicol 42:619-624 doi:10.1016/ j.fct.2003.11.006

Tolosa J, Font G, Manes J, Ferrer E (2014) Natural occurrence of emerging Fusarium mycotoxins in feed and fish from aquaculture. J Agric Food Chem 62:12462-12470. doi:10.1021/jf5036838

Ueno Y (1984) Toxicological features of T-2 toxin and related trichothecenes Fundam Appl Toxicol 4:S124-132

Vandenbroucke V, Croubels S, Verbrugghe E, Boyen F, De Backer P, Ducatelle R, Rychlik I, Haesebrouck F, Pasmans F (2009) The mycotoxin deoxynivalenol promotes uptake of Salmonella typhimurium in porcine macrophages, associated with ERK1/2 induced cytoskeleton reorganization. Vet Res 40(6):64 doi:10.1051/vetres/2009045

Wan LY, Turner PC, El-Nezami H (2013) Individual and combined cytotoxic effects of Fusarium toxins (deoxynivalenol, nivalenol, zearalenone and fumonisins B1) on swine jejunal epithelial cells Food Chem Toxicol 57:276-283 doi:10.1016/j.fct.2013.03.034

Wong S, Zhou HR, Marin-Martinez ML, Brooks K, Pestka JJ (1998) Modulation of IL-1beta, IL-6 and TNF-alpha secretion and mRNA expression by the trichothecene vomitoxin in the RAW $264.7 \mathrm{mu}-$ rine macrophage cell line. Food Chem Toxicol 6(5):409-419

Wong S, Schwartz RC, Pestka JJ (2001) Superinduction of TNF-alpha and IL- 6 in macrophages by vomitoxin (deoxynivalenol) modulated by mRNA stabilization. Toxicology 21;161(1-2):139-49

Yoshizawa T, Takeda H, Ohi T (1983) Structure of a novel metabolite from deoxynivalenol, a trichothecene mycotoxin, in animals. Agric Biol Chem 47:2133-2135. doi:10.1080/00021369.1983.10865926

Zhou HR, Harkema JR, Yan D, Pestka JJ (1999) Amplified proinflammatory cytokine expression and toxicity in mice coexposed to lipopolysaccharide and the trichothecene vomitoxin (deoxynivalenol). J Toxicol Environ Health 57(2):115-136. doi:10.1080/ 009841099157818 